\title{
Prostate cancer genomics: can we distinguish between indolent and fatal disease using genetic markers?
}

\author{
Fredrik Wiklund*
}

\begin{abstract}
Prostate cancer is one of the most heritable cancers in men, and recent genome-wide association studies have revealed numerous genetic variants associated with disease. The risk variants identified using casecontrol designs that compared unaffected individuals with all types of patients with prostate cancer show little or no ability to discriminate between indolent and fatal forms of this disease. This suggests different genetic components are involved in the initiation as compared with the prognosis of prostate cancer. Future studies contrasting patients with more and less aggressive disease, and exploring association with disease progression and prognosis, should be more effective in detecting genetic risk factors for prostate cancer outcome.
\end{abstract}

\section{Prostate cancer}

Prostate cancer constitutes a major health burden, being the most common non-cutaneous malignancy among men in developed countries. In 2007, almost 800,000 new cases of prostate cancer and 250,000 deaths from this disease were estimated to have occurred worldwide [1]. The highest incidence of prostate cancer is observed in the USA, with 192,280 new cases and 27,360 deaths expected in 2009, thereby being the second most common cause of cancer-related death [2]. Prostate cancer is a heterogeneous disease and its natural history is not completely understood. Early autopsy studies have shown a high prevalence of clinically undetected prostate cancer at time of death. In the USA, more than one in three men over 50 years of age had histologic evidence of prostate cancer at autopsy and this prevalence was observed to

*Correspondence: Fredrik.wiklund@ki.se

Department of Medical Epidemiology and Biostatistics, Karolinska Institutet, Bos 281, 17177 Stockholm, Sweden increase with age, with more than $67 \%$ of men aged over 80 years having prostate cancer at time of death [3]. These findings indicate that a high proportion of prostate tumors are clinically insignificant and will never lead to a lethal outcome. Furthermore, the introduction and widespread application of prostate-specific antigen (PSA) testing has led to increased detection of early-stage, lowvolume, non-palpable tumors. This has in turn raised concerns of increased overdiagnosis and unnecessary treatment of indolent disease $[4,5]$. To this end, new strategies to help clinicians distinguish between lethal and indolent prostate cancer are urgently needed. Prostate cancer is one of the most heritable cancers in men and recent studies have revealed numerous genetic variants associated with this disease. This review will give an overview of the current knowledge of prostate cancer genetics, with a special focus on the ability of genetic variants to predict more aggressive forms.

\section{Prostate cancer susceptibility variants}

A family history of prostate cancer is one of the strongest risk factors, and twin studies suggest that as much as $42 \%$ of the disease risk is explained by heritable factors [6]. Attempts to decipher the heritable component of prostate cancer based on candidate gene association studies and genome-wide linkage studies in multiple case families have suggested numerous prostate cancer susceptibility genes and loci. However, an inability to replicate reported linkage and association findings suggest that prostate cancer is genetically complex with multiple common low-penetrance genes involved in prostate cancer predisposition [7]. Recently, genome-wide association studies (GWAS) have emerged as a powerful method to identify genomic low-risk susceptibility regions for complex diseases, including cancer [8]. Through genotyping platforms that explore hundreds of thousands of single nucleotide polymorphisms (SNPs) simultaneously, it is possible to screen the complete genome for common genetic variation associated with the disease of interest. In 2006 the first prostate cancer susceptibility region was identified at chromosome 8q24. 
This region was initially identified through linkage analysis in Icelandic families with prostate cancer, followed up by association analysis in three independent case-control populations [9], and separately through admixture mapping in African Americans [10]. Subsequent GWAS and region-focused studies have revealed five distinct linkage disequilibrium blocks harboring prostate cancer susceptibility alleles at 8q24 [11-17]. The 8 q24 region has also been shown to harbor susceptibility alleles for breast cancer [18], colorectal cancer [19], bladder cancer [20], and ovarian cancer [14]. The 1.2 Mb sequence at 8q24 containing all observed risk alleles does not code for any known genes, and the biologic mechanisms underlying these associations are unknown. The oncogene $c-M y c$ is the closest distal gene to this region and it has been suggested that the observed associations reflect long-range control of $M y c$ expression; however, further functional studies are needed to reveal the role that these variants play in cancer susceptibility. To date, 29 distinct genetic loci harboring prostate cancer risk alleles have been identified and consistently replicated (Table 1). In general, the effect of variants in these regions on prostate cancer risk is modest, with odds ratios typically ranging between 1.1 and 1.3. It has been estimated [21] that hitherto identified variants together explain approximately $22 \%$ of the familial risk of prostate cancer, and it is anticipated that many more prostate cancer susceptibility variants will be identified in the future.

\section{Prostate cancer susceptibility variants and disease aggressiveness}

To date there is no reliable way of predicting whether prostate cancer will be an aggressive, fast-growing disease or a non-aggressive, slow-growing type of cancer. In general, a combination of tumor staging (using the tumor, node, metastasis staging system [22]), tumor grading (using the Gleason scoring system [23]) and diagnostic PSA serum levels are used to classify patients into different prognostic risk groups to guide clinicians in treatment decisions. In genetic association studies, patients with prostate cancer are commonly classified as having a more aggressive form of the disease if they fulfill any of the following criteria: (1) disease spread outside of the prostate gland, or presence of cancer in the lymph nodes or other metastatic sites; (2) presence of poorly differentiated cancer as indicated by a high Gleason score (that is, $4+3=7$ or higher); or (3) a serum PSA level associated with a high likelihood of extensive disease (that is, $>20 \mathrm{ng} / \mathrm{ml}$ ).

Several studies have explored the capacity of established prostate cancer risk variants to distinguish between less aggressive and more aggressive disease [9-13,24-46]. Overall, results are inconclusive, with some studies reporting stronger associations for some of these variants among patients with more aggressive prostate cancer, while others did not. In a large replication study from the PRACTICAL (Prostate Cancer Association Group to Investigate Cancer Associated Alterations in the Genome) consortium, which evaluated genetic variants at chromosome 3p12, 6q25, 7q21, 10q11, 11q13, 19q13 and Xp11 among 7,370 prostate cancer cases and 5,742 controls, no association with tumor grade was observed for any of the explored variants [45]. Fitzgerald and coworkers assessed the same seven variants and an additional six variants at chromosome 7p15, 8q24, 10q26, and $17 q 12$ in a population-based study comprising 1,308 cases and 1,267 controls for association with family history and clinical features of more aggressive disease [46]. No association was observed between any of the evaluated risk variants and a composite measure of disease aggressiveness; however, two variants, rs10993994 at 10q11 $(P=0.02)$ and rs5945619 at Xp11 $(P=0.03)$, were nominally significantly associated with Gleason score.

Most of the published studies exploring established risk variants with respect to prostate cancer aggressiveness have had several limitations, including small sample size, heterogeneous definition of aggressive disease across multiple study populations, and reliance on clinical grading and staging of tumors. To address these limitations, Kader and coworkers evaluated 20 established risk variants in 17 distinct genomic regions among 5,895 patients with prostate cancer who were of European descent and who underwent radical prostatectomy for treatment of prostate cancer [47]. Based on the entire prostate gland, each tumor was uniformly graded and staged using the same protocol. Tumors with pathologic Gleason scores of $4+3$ or higher, or pathologic stage of T3b or higher, or non-organ confined disease, were defined as more aggressive disease $(N=1,253)$; tumors with organ confined disease, pathologic Gleason score of $3+4$ or lower, and pathologic stage of T2 were classified as less aggressive disease $(N=4,233)$. For 18 of the 20 variants explored, no significant difference was observed in risk allele frequencies between patients with more aggressive and less aggressive disease. Two variants were significantly associated with disease aggressiveness: SNP rs2735839 downstream of the kallikrein 3 gene (KLK3; $\left.P=8.4 \times 10^{-7}\right)$, which is the gene coding for PSA; and SNP rs10993994 in the microseminoprotein $\beta$ gene (MSMB; $P=0.046)$. To reduce the possible impact of heterogeneity in the definition of aggressive disease, risk variants were also tested for association with Gleason score and pathological stage separately. SNP rs2735839 in the $K L K 3$ gene $\left(P=7.7 \times 10^{-6}\right)$ and SNP rs10993994 in the MSMB gene $(P=0.02)$ were the only variants associated with Gleason score. For tumor stage, only SNP rs2735839 in the $K L K 3$ gene was significant $\left(P=1.9 \times 10^{-4}\right)$. Of note, 
Table 1. Established prostate cancer susceptibility alleles

\begin{tabular}{|c|c|c|c|c|}
\hline dbSNP number & Chromosome & Gene $^{a}$ & Risk allele ${ }^{b}$ & Study \\
\hline rs1465618 & $2 p 21$ & THADA & A & Eeles et al. 2009 [21] \\
\hline rs721048 & $2 p 15$ & EHBP1 & $A$ & Gudmundsson et al. 2008 [27] \\
\hline rs12621278 & $2 q 31.1$ & ITGA6 & A & Eeles et al. 2009 [21] \\
\hline rs4857841 & $3 q 21.3$ & EEFSEC & $A$ & Gudmundsson et al. 2009 [57] \\
\hline rs12500426 & $4 q 22.3$ & PDLIM5 & A & Eeles et al. 2009 [21] \\
\hline rs17021918 & $4 q 22.3$ & PDLIM5 & C & Eeles et al. 2009 [21] \\
\hline rs7679673 & $4 q 24$ & FLJ20032 & C & Eeles et al. 2009 [21] \\
\hline rs9364554 & $6 q 25.3$ & SLC22A3 & $T$ & Eeles et al. 2008 [28] \\
\hline rs10486567 & $7 p 15.2$ & $J A Z F 1$ & G & Thomas et al. 2008 [26] \\
\hline rs6465657 & $7 q 21.3$ & LMTK2 & C & Eeles et al. 2008 [28] \\
\hline rs1512268 & $8 p 21.2$ & $N K X 3-1$ & $T$ & Eeles et al. 2009 [21] \\
\hline rs12543663 & $8 q 24.21$ & & C & Al Olama et al. 2009 [16] \\
\hline rs10086908 & $8 q 24.21$ & & $T$ & Al Olama et al. 2009 [16] \\
\hline rs1016343 & $8 q 24.21$ & & $\mathrm{~T}$ & Al Olama et al. 2009 [16] \\
\hline rs13252298 & $8 q 24.21$ & & $A$ & Al Olama et al. 2009 [16] \\
\hline rs6983561 & $8 q 24.21$ & & C & Al Olama et al. 2009 [16] \\
\hline rs16901979 & $8 q 24.21$ & & A & Gudmundsson et al. 2007 [11] \\
\hline rs16902094 & $8 q 24.21$ & & G & Gudmundsson et al. 2009 [57] \\
\hline rs445114 & $8 q 24.21$ & & $T$ & Gudmundsson et al. 2009 [57] \\
\hline rs620861 & $8 q 24.21$ & & C & Al Olama et al. 2009 [16] \\
\hline rs6983267 & $8 q 24.21$ & & G & Al Olama et al. 2009 [16] \\
\hline rs1447295 & $8 q 24.21$ & & A & Amundadottir et al. 2006 [9] \\
\hline rs10993994 & $10 q 11.23$ & $M S M B$ & $\mathrm{~T}$ & Eeles et al. 2008 [28] \\
\hline rs4962416 & $10 q 26.13$ & CTBP2 & C & Thomas et al. 2008 [26] \\
\hline rs7127900 & $11 \mathrm{p} 15.5$ & & $A$ & Eeles et al. 2009 [21] \\
\hline rs12418451 & $11 q 13.2$ & & A & Zheng et al. 2009 [34] \\
\hline rs11228565 & $11 q 13.2$ & & A & Gudmundsson et al. 2009 [57] \\
\hline rs10896449 & $11 \mathrm{q} 13.2$ & & G & Thomas et al. 2008 [26] \\
\hline rs11649743 & $17 q 12$ & HNFIB & G & Sun et al. 2008 [30] \\
\hline rs4430796 & $17 q 12$ & HNFIB & $A$ & Gudmundsson et al. 2007 [11] \\
\hline rs1859962 & $17 q 24.3$ & & G & Gudmundsson et al. 2007 [11] \\
\hline rs8102476 & $19 q 13.2$ & PPP1R14A & C & Gudmundsson et al. 2009 [57] \\
\hline rs2735839 & $19 q 13.33$ & $K L K 3$ & $A$ & Eeles et al. 2008 [28] \\
\hline rs9623117 & $22 q 13.1$ & TNRC6B & C & Sun et al. 2009 [31] \\
\hline rs5759167 & $22 q 13.2$ & $B I K$ & G & Eeles et al. 2009 [21] \\
\hline rs5945619 & Xp11.22 & NUDT11 & C & Eeles et al. 2008 [28] \\
\hline
\end{tabular}

aGenes within the linkage-disequilibrium block defined by the associated variant: BIK, BCL2-interacting killer; CTBP2, C-terminal binding protein 2 isoform 2; EEFSEC, elongation factor for selenoprotein translation; EHBP1, EH domain binding protein 1; FLJ20032, hypothetical protein LOC54790; HNF1B, hepatocyte nuclear factor 1 homeobox $B$; ITGA6, integrin alpha chain 6; JAZF1, juxtaposed with another zinc finger gene 1; KLK3, kallikrein 3; LMTK2, lemur tyrosine kinase 2; MSMB, $\beta$-microseminoprotein isoform a precursor; NKX3-1, NK3 transcription factor related locus 1; NUDT11, nudix-type motif 11; PDLIM5, PDZ and LIM domain 5 isoform d; PPP1R14A, protein phosphatase 1 regulatory inhibitor; SLC22A3, solute carrier family 22 member 3; SLC25A37, mitochondrial solute carrier protein; THADA, thyroid adenoma associated isoform $1 ; T N R C 6 B$, trinucleotide repeat containing $6 \mathrm{~B}$ isoform 2. ${ }^{\circ}$ Risk alleles as defined from published data cited in the column.

for both of these variants, the alleles that are associated with increased risk for prostate cancer were more frequent in patients with less aggressive disease. Since these risk alleles have been shown to strongly associate with higher PSA levels among population controls $[28,48,49]$, it is possible that the observed association with aggressive disease may partly reflect a PSA detection bias. 
It should be noted that the lack of association between established prostate cancer risk variants and disease aggressiveness does not imply non-existence of such genetic variants in the genome. All susceptibility variants identified to date were discovered using case-control designs comparing unaffected individuals with all types of patients with prostate cancer. It has been argued that a more effective design to identify genetic variants associated with aggressive disease should involve a casecase design contrasting patients with more and less aggressive disease. Support for this idea was recently provided in a study including 4,829 patients with more aggressive disease and 12,205 patients with less aggressive disease from seven study populations [50]. Initially, publicly available genotype data for approximately 27,000 genetic variants across the genome were explored for association with disease severity among patients with prostate cancer from four populations examined in the Cancer Genetic Markers of Susceptibility study using a case-case design. A subset of variants $(n=74)$, showing association within each Cancer Genetic Markers of Susceptibility study, and where the direction of association was consistent among all four studies, was selected for further evaluation in an additional three study populations from Sweden and the USA. This revealed one genetic variant (rs4054823 at 17p12) for which the TT genotype was consistently higher among patients with more aggressive compared with less aggressive disease in each of the seven populations studied (overall $P=2.1 \times 10^{-8}$ under a recessive genetic model). If confirmed in independent study populations, this finding is of great importance, not because of immediate clinical utility, but as a proof of principle that genetic variants predisposing to more aggressive prostate cancer exist.

\section{Prostate cancer susceptibility variants and disease progression and prognosis}

In contrast to exploring inherited genetic variants associated with aggressiveness of disease at time of diagnosis, only a few studies have assessed the importance of established risk variants on prostate cancer progression and prognosis.

Only one study has explored confirmed risk variants in relation to prostate cancer progression. Among 320 patients who were recruited from three hospitals in Taiwan where they were treated with radical prostatectomy, Huang and co-workers explored association between 20 prostate cancer risk variants and biochemical failure defined by recurrence of PSA [51]. During a mean follow-up of 38.5 months, biochemical failure occurred in 113 (35\%) of the patients. In univariate analysis, three risk variants (rs1447295 at 8q24, and rs7920517 and rs10993994 at 10q11) were associated with PSA recurrence. Interestingly, these associations remained significant after adjusting for established prognostic factors such as age, preoperative PSA level, tumor stage, Gleason score, and surgical margin, suggesting that these variants may improve prediction of PSA recurrence among patients treated with radical prostatectomy. Further studies are required to validate these findings.

Penney and co-workers [52] explored eight genetic variants at chromosome $8 \mathrm{q} 24,17 \mathrm{q} 12$, and $17 \mathrm{q} 24.3$ for association with prostate cancer mortality in three US prostate cancer study populations comprising a total of 6,460 patients of which 493 died as a result of prostate cancer during follow-up. None of the explored variants was associated with prostate cancer mortality, neither in analysis contrasting lethal cases with long-time survivors (alive over 10 years after diagnosis), nor in survival analysis among all patients. The total number of risk alleles was also not associated with prostate cancer mortality.

A prospective population-based cohort study of Swedish patients with prostate cancer explored the association between 16 established risk variants and prostate cancer mortality [52]. In total, 2,875 patients diagnosed between 2001 and 2003 were followed up for prostate cancer mortality through January 2008. Overall, 626 (21\%) of the patients died during follow-up and of those 440 (15\%) had prostate cancer classified as their underlying cause of death. No association between any of the explored variants and prostate cancer mortality was observed, either in exploring individual variants or in assessing the cumulative effect of all variants.

Additional studies in large populations are needed to comprehensively explore possible associations, although current evidence suggests that established risk variants are not risk factors for prostate cancer outcome.

\section{Future clinical use of genetic factors}

Recent GWAS studies have been successful in identifying many low-penetrant susceptibility alleles for prostate cancer, and it is anticipated that many more variants will be detected through combined analysis across existing studies, new generations of larger studies, and increasing size of replication studies. Individually, each risk variant has a modest effect on disease risk and they will clearly not be useful for individualized risk prediction. However, risk profiles based on a combination of risk variants lead to an appreciable increased risk of disease [35] and there is potential for the predictive power to increase considerably as more risk variants are detected [53]. This may have important implications for targeted prevention and screening programs for prostate cancer through identification of high-risk groups.

Since there is considerable co-morbidity associated with curative treatment of prostate cancer (surgery or radiotherapy), there is clear clinical utility in detecting 
genetic markers that can improve discrimination between those patients that will follow a benign course from those with tumors that carry a poor prognosis and for whom curative therapy is indicated. In addition, inherited genetic markers, in contrast to measurement of a tumorderived product, can be informative at an earlier stage when the disease is potentially curable. However, it is evident that hitherto identified prostate cancer risk variants provide little or no discriminative capacity between indolent and aggressive forms of prostate cancer. Large GWAS among affected men contrasting more and less aggressive cases, and exploring association with disease progression and prostate cancer mortality, are clearly needed to detect inherited genetic variants associated with aggressive forms of prostate cancer. Initial findings indicate that genetic variants predisposing to more aggressive disease exist [50] and this is also supported by recent epidemiological studies proposing a genetic component in cancer prognosis [54,55].

The detection of inherited genetic markers capable of discriminating between indolent and fatal forms of prostate cancer holds promise to improve detection and clinical management of this disease in several ways. A genetic-based, targeted PSA screening strategy may reduce both overdiagnosis and mortality by identifying those men at risk for fatal prostate cancer at a curable stage. In addition, extended tools to guide clinicians in treatment decisions are critical to improve disease prognosis and decrease treatment-induced morbidity.

\section{Abbreviations}

GWAS, genome-wide association study; PSA, prostate-specific antigen; SNP, single-nucleotide polymorphism.

\section{Competing interests}

The author declares that he has no competing interests.

Published: 28 July 2010

\section{References}

1. Crawford ED: Understanding the epidemiology, natural history, and key pathways involved in prostate cancer. Urology 2009, 73:54-10

2. Jemal A, Siegel R, Ward E, Hao Y, Xu J, Thun MJ: Cancer statistics, 2009. CA Cancer J Clin 2009, 59:225-249.

3. Yatani R, Chigusa I, Akazaki K, Stemmermann GN, Welsh RA, Correa P: Geographic pathology of latent prostatic carcinoma. Int J Cancer 1982, 29:611-616.

4. Draisma G, Etzioni R, Tsodikov A, Mariotto A, Wever E, Gulati R, Feuer E, de Koning $\mathrm{H}$ : Lead time and overdiagnosis in prostate-specific antigen screening: importance of methods and context. J Nat/ Cancer Inst 2009, 101:374-383.

5. Welch $\mathrm{HG}$, Albertsen PC: Prostate cancer diagnosis and treatment after the introduction of prostate-specific antigen screening: 1986-2005. J Natl Cancer Inst 2009, 101:1325-1329.

6. Lichtenstein P, Holm NV, Verkasalo PK, Iliadou A, Kaprio J, Koskenvuo M, Pukkala E, Skytthe A, Hemminki K: Environmental and heritable factors in the causation of cancer - analyses of cohorts of twins from Sweden, Denmark, and Finland. N Engl J Med 2000, 343:78-85.

7. Schaid DJ: The complex genetic epidemiology of prostate cancer. Hum Mol Genet 2004, 13 Spec No 1:R103-121.

8. Chung CC, Magalhaes WC, Gonzalez-Bosquet J, Chanock SJ: Genome-wide association studies in cancer - current and future directions. Carcinogenesis 2010, 31:111-120.
9. Amundadottir LT, Sulem P, Gudmundsson J, Helgason A, Baker A, Agnarsson BA, Sigurdsson A, Benediktsdottir KR, Cazier JB, Sainz J, Jakobsdottir M, Kostic J, Magnusdottir DN, Ghosh S, Agnarsson K, Birgisdottir B, Le Roux L, Olafsdottir A, Blondal T, Andresdottir M, Gretarsdottir OS, Bergthorsson JT, Gudbjartsson D, Gylfason A, Thorleifsson G, Manolescu A, Kristjansson K, Geirsson G, Isaksson H, Douglas J, et al.: A common variant associated with prostate cancer in European and African populations. Nat Genet 2006, 38:652-658.

10. Freedman ML, Haiman CA, Patterson N, McDonald GJ, Tandon A, Waliszewska A, Penney K, Steen RG, Ardlie K, John EM, Oakley-Girvan I, Whittemore AS, Cooney KA, Ingles SA, Altshuler D, Henderson BE, Reich D: Admixture mapping identifies $8 \mathrm{q} 24$ as a prostate cancer risk locus in AfricanAmerican men. Proc Natl Acad Sci U S A 2006, 103:14068-14073.

11. Gudmundsson J, Sulem P, Manolescu A, Amundadottir LT, Gudbjartsson D, Helgason A, Rafnar T, Bergthorsson JT, Agnarsson BA, Baker A, Sigurdsson A, Benediktsdottir KR, Jakobsdottir M, Xu J, Blondal T, Kostic J, Sun J, Ghosh S, Stacey SN, Mouy M, Saemundsdottir J, Backman VM, Kristjansson K, Tres A, Partin AW, Albers-Akkers MT, Godino-Ivan Marcos J, Walsh PC, Swinkels DW, Navarrete S, et al.: Genome-wide association study identifies a second prostate cancer susceptibility variant at 8q24. Nat Genet 2007, 39:631-637.

12. Haiman CA, Patterson N, Freedman ML, Myers SR, Pike MC, Waliszewska A, Neubauer J, Tandon A, Schirmer C, McDonald GJ, Greenway SC, Stram DO, Le Marchand L, Kolonel LN, Frasco M, Wong D, Pooler LC, Ardlie K, Oakley-Girvan I, Whittemore AS, Cooney KA, John EM, Ingles SA, Altshuler D, Henderson BE, Reich D: Multiple regions within 8q24 independently affect risk for prostate cancer. Nat Genet 2007, 39:638-644.

13. Zheng SL, Sun J, Cheng Y, Li G, Hsu FC, Zhu Y, Chang BL, Liu W, Kim JW, Turner AR, Gielzak M, Yan G, Isaacs SD, Wiley KE, Sauvageot J, Chen HS, Gurganus R, Mangold LA, Trock BJ, Gronberg H, Duggan D, Carpten JD, Partin AW, Walsh $P C, X u$ J, Isaacs WB: Association between two unlinked loci at 8q24 and prostate cancer risk among European Americans. J Nat C Cancer Inst 2007, 99:1525-1533.

14. Ghoussaini M, Song H, Koessler T, Al Olama AA, Kote-Jarai Z, Driver KE, Pooley KA, Ramus SJ, Kjaer SK, Hogdall E, DiCioccio RA, Whittemore AS, Gayther SA, Giles GG, Guy M, Edwards SM, Morrison J, Donovan JL, Hamdy FC, Dearnaley DP, Ardern-Jones AT, Hall AL, O'Brien LT, Gehr-Swain BN, Wilkinson RA, Brown PM, Hopper JL, Neal DE, Pharoah PD, Ponder BA, et al.: Multiple loci with different cancer specificities within the $8 q 24$ gene desert. J Nat/ Cancer Inst 2008, 100:962-966.

15. Yeager M, Xiao N, Hayes RB, Bouffard P, Desany B, Burdett L, Orr N, Matthews C, Qi L, Crenshaw A, Markovic Z, Fredrikson KM, Jacobs KB, Amundadottir L, Jarvie TP, Hunter DJ, Hoover R, Thomas G, Harkins TT, Chanock SJ: Comprehensive resequence analysis of a $136 \mathrm{~kb}$ region of human chromosome $8 \mathrm{q} 24$ associated with prostate and colon cancers. Hum Genet 2008, 124:161-170

16. Al Olama AA, Kote-Jarai Z, Giles GG, Guy M, Morrison J, Severi G, Leongamornlert DA, Tymrakiewicz M, Jhavar S, Saunders E, Hopper JL, Southey MC, Muir KR, English DR, Dearnaley DP, Ardern-Jones AT, Hall AL, O'Brien LT, Wilkinson RA, Sawyer E, Lophatananon A, Horwich A, Huddart RA, Khoo VS, Parker CC, Woodhouse CJ, Thompson A, Christmas T, Ogden C, Cooper C, et al:: Multiple loci on 8q24 associated with prostate cancer susceptibility. Nat Genet 2009, 41:1058-1060.

17. Yeager M, Chatterjee N, Ciampa J, Jacobs KB, Gonzalez-Bosquet J, Hayes RB, Kraft P, Wacholder S, Orr N, Berndt S, Yu K, Hutchinson A, Wang Z, Amundadottir L, Feigelson HS, Thun MJ, Diver WR, Albanes D, Virtamo J, Weinstein S, Schumacher FR, Cancel-Tassin G, Cussenot O, Valeri A, Andriole GL, Crawford ED, Haiman CA, Henderson B, Kolonel L, Le Marchand L, et al:: Identification of a new prostate cancer susceptibility locus on chromosome 8q24. Nat Genet 2009, 41:1055-1057.

18. Easton DF, Pooley KA, Dunning AM, Pharoah PD, Thompson D, Ballinger DG, Struewing JP, Morrison J, Field H, Luben R, Wareham N, Ahmed S, Healey CS, Bowman R, Meyer KB, Haiman CA, Kolonel LK, Henderson BE, Le Marchand L, Brennan P, Sangrajrang S, Gaborieau V, Odefrey F, Shen CY, Wu PE, Wang HC, Eccles D, Evans DG, Peto J, Fletcher O, et al:: Genome-wide association study identifies novel breast cancer susceptibility loci. Nature 2007, 447:1087-1093.

19. Tomlinson I, Webb E, Carvajal-Carmona L, Broderick P, Kemp Z, Spain S, Penegar S, Chandler I, Gorman M, Wood W, Barclay E, Lubbe S, Martin L, Sellick G, Jaeger E, Hubner R, Wild R, Rowan A, Fielding S, Howarth K, Silver A, Atkin W, Muir K, Logan R, Kerr D, Johnstone E, Sieber O, Gray R, Thomas H, Peto J, et al:: A genome-wide association scan of tag SNPs identifies a 
susceptibility variant for colorectal cancer at 8q24.21. Nat Genet 2007 39:984-988.

20. Kiemeney LA, Thorlacius S, Sulem P, Geller F, Aben KK, Stacey SN, Gudmundsson J, Jakobsdottir M, Bergthorsson JT, Sigurdsson A, Blondal T, Witjes JA, Vermeulen SH, Hulsbergen-van de Kaa CA, Swinkels DW, Ploeg M, Cornel EB, Vergunst H, Thorgeirsson TE, Gudbjartsson D, Gudjonsson SA, Thorleifsson G, Kristinsson KT, Mouy M, Snorradottir S, Placidi D, Campagna M, Arici C, Koppova K, Gurzau E, et al.: Sequence variant on 8q24 confers susceptibility to urinary bladder cancer. Nat Genet 2008, 40:1307-1312.

21. Eeles RA, Kote-Jarai Z, Al Olama AA, Giles GG, Guy M, Severi G, Muir K, Hopper JL, Henderson BE, Haiman CA, Schleutker J, Hamdy FC, Neal DE, Donovan JL, Stanford JL, Ostrander EA, Ingles SA, John EM, Thibodeau SN, Schaid D, Park JY, Spurdle A, Clements J, Dickinson JL, Maier C, Vogel W, Dork T, Rebbeck TR, Cooney KA, Cannon-Albright L, et al: Identification of seven new prostate cancer susceptibility loci through a genome-wide association study. Nat Genet 2009, 41:1116-1121.

22. Hoedemaeker RF, Vis AN, Van Der Kwast TH: Staging prostate cancer. Microsc Res Tech 2000, 51:423-429.

23. Epstein Jl, AllsbrookWC Jr, Amin MB, Egevad LL: The 2005 International Society of Urological Pathology (ISUP) Consensus Conference on Gleason Grading of Prostatic Carcinoma. Am J Surg Pathol 2005, 29:1228-1242.

24. Yeager M, Orr N, Hayes RB, Jacobs KB, Kraft P. Wacholder S, Minichiello MJ, Fearnhead P, Yu K, Chatterjee N, Wang Z, Welch R, Staats BJ, Calle EE, Feigelson HS, Thun MJ, Rodriguez C, Albanes D, Virtamo J, Weinstein S, Schumacher FR, Giovannucci E, Willett WC, Cancel-Tassin G, Cussenot O, Valeri A, Andriole GL, Gelmann EP, Tucker M, Gerhard DS, et al:: Genome-wide association study of prostate cancer identifies a second risk locus at 8q24. Nat Genet 2007, 39:645-649

25. Gudmundsson J, Sulem P, Steinthorsdottir V, Bergthorsson JT, Thorleifsson G Manolescu A, Rafnar T, Gudbjartsson D, Agnarsson BA, Baker A, Sigurdsson A, Benediktsdottir KR, Jakobsdottir M, Blondal T, Stacey SN, Helgason A, Gunnarsdottir S, Olafsdottir A, Kristinsson KT, Birgisdottir B, Ghosh S, Thorlacius S, Magnusdottir D, Stefansdottir G, Kristjansson K, Bagger Y, Wilensky RL, Reilly MP, Morris AD, Kimber CH, et al:: Two variants on chromosome 17 confer prostate cancer risk, and the one in TCF 2 protects against type 2 diabetes. Nat Genet 2007, 39:977-983.

26. Thomas G, Jacobs KB, Yeager M, Kraft P, Wacholder S, Orr N, Yu K, Chatterjee N, Welch R, Hutchinson A, Crenshaw A, Cancel-Tassin G, Staats BJ, Wang Z, Gonzalez-Bosquet J, Fang J, Deng X, Berndt SI, Calle EE, Feigelson HS, Thun MJ, Rodriguez C, Albanes D, Virtamo J, Weinstein S, Schumacher FR, Giovannucci E, Willett WC, Cussenot O, Valeri A, et al: Multiple loci identified in a genome-wide association study of prostate cancer. Nat Genet 2008, 40:310-315.

27. Gudmundsson J, Sulem P, Rafnar T, Bergthorsson JT, Manolescu A, Gudbjartsson D, Agnarsson BA, Sigurdsson A, Benediktsdottir KR, Blondal T, Jakobsdottir M, Stacey SN, Kostic J, Kristinsson KT, Birgisdottir B, Ghosh S, Magnusdottir DN, Thorlacius S, Thorleifsson G, Zheng SL, Sun J, Chang BL, Elmore JB, Breyer JP, McReynolds KM, Bradley KM, Yaspan BL, Wiklund F, Stattin P, Lindstrom S, et al: Common sequence variants on $2 \mathrm{p} 15$ and Xp11.22 confer susceptibility to prostate cancer. Nat Genet 2008, 40:281-283

28. Eeles RA, Kote-Jarai Z, Giles GG, Olama AA, Guy M, Jugurnauth SK, Mulholland S, Leongamornlert DA, Edwards SM, Morrison J, Field HI, Southey MC, Severi G, Donovan JL, Hamdy FC, Dearnaley DP, Muir KR, Smith C, Bagnato M, Ardern-Jones AT, Hall AL, O'Brien LT, Gehr-Swain BN, Wilkinson RA, Cox A, Lewis S, Brown PM, Jhavar SG, Tymrakiewicz M, Lophatananon A, et al:: Multiple newly identified loci associated with prostate cancer susceptibility. Nat Genet 2008, 40:316-321.

29. Duggan D, Zheng SL, Knowlton M, Benitez D, Dimitrov L, Wiklund F, Robbins C, Isaacs SD, Cheng Y, Li G, Sun J, Chang BL, Marovich L, Wiley KE, Balter K, Stattin P, Adami HO, Gielzak M, Yan G, Sauvageot J, Liu W, Kim JW, Bleecker ER, Meyers DA, Trock BJ, Partin AW, Walsh PC, Isaacs WB, Gronberg H, Xu J, et al.: Two genome-wide association studies of aggressive prostate cancer implicate putative prostate tumor suppressor gene DAB2IP. J Nat/ Cancer Inst 2007, 99:1836-1844.

30. Sun J, Zheng SL, Wiklund F, Isaacs SD, Purcell LD, Gao Z, Hsu FC, Kim ST, Liu W, Zhu Y, Stattin P, Adami HO, Wiley KE, Dimitrov L, Li T, Turner AR, Adams TS, Adolfsson J, Johansson JE, Lowey J, Trock BJ, Partin AW, Walsh PC, Trent JM, Duggan D, Carpten J, Chang BL, Gronberg H, Isaacs WB, Xu J: Evidence for two independent prostate cancer risk-associated loci in the HNF1B gene at 17q12. Nat Genet 2008, 40:1153-1155.
31. Sun J, Zheng SL, Wiklund F, Isaacs SD, Li G, Wiley KE, Kim ST, Zhu Y, Zhang Z Hsu FC, Turner AR, Stattin P, Liu W, Kim JW, Duggan D, Carpten J, Isaacs W, Gronberg H, Xu J, Chang BL: Sequence variants at 22q13 are associated with prostate cancer risk. Cancer Res 2009, 69:10-15.

32. Chang BL, Cramer SD, Wiklund F, Isaacs SD, Stevens VL, Sun J, Smith S, Pruett K, Romero LM, Wiley KE, Kim ST, Zhu Y, Zhang Z, Hsu FC, Turner AR, Adolfsson J, Liu W, Kim JW, Duggan D, Carpten J, Zheng SL, Rodriguez C, Isaacs WB, Gronberg $\mathrm{H}, \mathrm{Xu}$ J: Fine mapping association study and functional analysis implicate a SNP in MSMB at 10q11 as a causal variant for prostate cancer risk. Hum Mol Genet 2009, 18:1368-1375.

33. Hsu FC, Sun J, Wiklund F, Isaacs SD, Wiley KE, Purcell LD, Gao Z, Stattin P, Zhu Y, Kim ST, Zhang Z, Liu W, Chang BL, Walsh PC, Duggan D, Carpten JD, Isaacs WB, Gronberg H, XU J, Zheng SL: A novel prostate cancer susceptibility locus at 19q13. Cancer Res 2009, 69:2720-2723.

34. Zheng SL, Stevens VL, Wiklund F, Isaacs SD, Sun J, Smith S, Pruett K, Wiley KE, Kim ST, Zhu Y, Zhang Z, Hsu FC, Turner AR, Johansson JE, Liu W, Kim JW, Chang BL, Duggan D, Carpten J, Rodriguez C, Isaacs W, Gronberg H, Xu J: Two independent prostate cancer risk-associated Loci at 11q13. Cancer Epidemiol Biomarkers Prev 2009, 18:1815-1820

35. Zheng SL, Sun J, Wiklund F, Smith S, Stattin P, Li G, Adami HO, Hsu FC, Zhu Y, Balter K, Kader AK, Turner AR, Liu W, Bleecker ER, Meyers DA, Duggan D, Carpten JD, Chang BL, Isaacs WB, Xu J, Gronberg H: Cumulative association of five genetic variants with prostate cancer. N Eng/ J Med 2008, 358:910-919.

36. Sun J, Chang BL, Isaacs SD, Wiley KE, Wiklund F, Stattin P, Duggan D, Carpten JD, Trock BJ, Partin AW, Walsh PC, Gronberg H, Xu J, Isaacs WB, Zheng SL: Cumulative effect of five genetic variants on prostate cancer risk in multiple study populations. Prostate 2008, 68:1257-1262.

37. Xu J, Isaacs SD, Sun J, Li G, Wiley KE, Zhu Y, Hsu FC, Wiklund F, Turner AR, Adams TS, Liu W, Trock BJ, Partin AW, Chang B, Walsh PC, Gronberg H, Isaacs $W$, Zheng S: Association of prostate cancer risk variants with clinicopathologic characteristics of the disease. Clin Cancer Res 2008, 14:5819-5824.

38. Wang L, McDonnell SK, Slusser JP, Hebbring SJ, Cunningham JM, Jacobsen SJ, Cerhan JR, Blute ML, Schaid DJ, Thibodeau SN: Two common chromosome $8 \mathrm{q} 24$ variants are associated with increased risk for prostate cancer. Cancer Res 2007, 67:2944-2950.

39. Suuriniemi M, Agalliu I, Schaid DJ, Johanneson B, McDonnell SK, Iwasaki L, Stanford JL, Ostrander EA: Confirmation of a positive association between prostate cancer risk and a locus at chromosome 8q24. Cancer Epidemiol Biomarkers Prev 2007, 16:809-814.

40. Cheng I, Plummer SJ, Jorgenson E, Liu X, Rybicki BA, Casey G, Witte JS: $8 \mathrm{q} 24$ and prostate cancer: association with advanced disease and meta-analysis. Eur J Hum Genet 2008, 16:496-505.

41. Helfand BT, Loeb S, Cashy J, Meeks JJ, Thaxton CS, Han M, Catalona WJ: Tumor characteristics of carriers and noncarriers of the deCODE 8q24 prostate cancer susceptibility alleles. J Urol 2008, 179:2197-2201; discussion 2202.

42. Tan YC, Zeigler-Johnson C, Mittal RD, Mandhani A, Mital B, Rebbeck TR, Rennert H: Common 8q24 sequence variations are associated with Asian Indian advanced prostate cancer risk. Cancer Epidemiol Biomarkers Prev 2008, 17:2431-2435.

43. Terada N, Tsuchiya N, Ma Z, Shimizu Y, Kobayashi T, Nakamura E, Kamoto T, Habuchi T, Ogawa O: Association of genetic polymorphisms at 8q24 with the risk of prostate cancer in a Japanese population. Prostate 2008, 68:1689-1695.

44. Robbins C, Torres JB, Hooker S, Bonilla C, Hernandez W, Candreva A, Ahaghotu C, Kittles R, Carpten J: Confirmation study of prostate cancer risk variants at 8q24 in African Americans identifies a novel risk locus. Genome Res 2007, 17:1717-1722.

45. Kote-Jarai Z, Easton DF, Stanford JL, Ostrander EA, Schleutker J, Ingles SA Schaid D, Thibodeau S, Dork T, Neal D, Donovan J, Hamdy F, Cox A, Maier C, Vogel W, Guy M, Muir K, Lophatananon A, Kedda MA, Spurdle A, Steginga S, John EM, Giles G, Hopper J, Chappuis PO, Hutter P, Foulkes WD, Hamel N, Salinas CA, Koopmeiners JS, et al: Multiple novel prostate cancer predisposition loci confirmed by an international study: the PRACTICAL Consortium. Cancer Epidemiol Biomarkers Prev 2008, 17:2052-2061.

46. Fitzgerald LM, Kwon EM, Koopmeiners JS, Salinas CA, Stanford JL, Ostrander EA: Analysis of recently identified prostate cancer susceptibility loci in a population-based study: associations with family history and clinical features. Clin Cancer Res 2009, 15:3231-3237.

47. Kader AK, Sun J, Isaacs SD, Wiley KE, Yan G, Kim ST, Fedor H, DeMarzo AM 
Epstein JI, Walsh PC, Partin AW, Trock B, Zheng SL, Xu J, Isaacs W: Individual and cumulative effect of prostate cancer risk-associated variants on clinicopathologic variables in 5,895 prostate cancer patients. Prostate 2009, 69:1195-1205

48. Ahn J, Berndt SI, Wacholder S, Kraft P, Kibel AS, Yeager M, Albanes D, Giovannucci E, Stampfer MJ, Virtamo J, Thun MJ, Feigelson HS, Cancel-Tassin G, Cussenot O, Thomas G, Hunter DJ, Fraumeni JF Jr, Hoover RN, Chanock SJ, Hayes RB: Variation in KLK genes, prostate-specific antigen and risk of prostate cancer. Nat Genet 2008, 40:1032-1034; author reply 1035-1036.

49. Wiklund F, Zheng SL, Sun J, Adami HO, Lilja H, Hsu FC, Stattin P, Adolfsson J, Cramer SD, Duggan D, Carpten JD, Chang BL, Isaacs WB, Gronberg H, Xu J: Association of reported prostate cancer risk alleles with PSA levels among men without a diagnosis of prostate cancer. Prostate 2009, 69:419-427.

50. Xu J, Zheng SL, Isaacs SD, Wiley KE, Wiklund F, Sun J, Kader AK, Li G, Purcell LD, Kim ST, Hsu FC, Stattin P, Hugosson J, Adolfsson J, Walsh PC, Trent JM, Duggan D, Carpten J, Gronberg H, Isaacs WB: Inherited genetic variant predisposes to aggressive but not indolent prostate cancer. Proc Natl Acad Sci U SA 2010, 107:2136-2140.

51. Huang SP, Huang LC, Ting WC, Chen LM, Chang TY, Lu TL, Lan YH, Liu CC, Yang WH, Lee HZ, Hsieh CJ, Bao BY: Prognostic significance of prostate cancer susceptibility variants on prostate-specific antigen recurrence after radical prostatectomy. Cancer Epidemiol Biomarkers Prev 2009, 18:3068-3074.

52. Penney KL, Salinas CA, Pomerantz M, Schumacher FR, Beckwith CA, Lee GS, Oh WK, Sartor O, Ostrander EA, Kurth T, Ma J, Mucci L, Stanford JL, Kantoff PW, Hunter DJ, Stampfer MJ, Freedman ML: Evaluation of 8q24 and 17q risk loci and prostate cancer mortality. Clin Cancer Res 2009, 15:3223-3230
53. Wiklund FE, Adami HO, Zheng SL, Stattin P, Isaacs WB, Gronberg H, Xu J: Established prostate cancer susceptibility variants are not associated with disease outcome. Cancer Epidemiol Biomarkers Prev 2009, 18:1659-1662.

54. Pharoah PD, Antoniou AC, Easton DF, Ponder BA: Polygenes, risk prediction, and targeted prevention of breast cancer. N Engl J Med 2008, 358:2796-2803.

55. Hartman M, Lindstrom L, Dickman PW, Adami HO, Hall P, Czene K: Is breast cancer prognosis inherited? Breast Cancer Res 2007, 9:R39.

56. Lindstrom LS, Hall P, Hartman M, Wiklund F, Gronberg H, Czene K: Familial concordance in cancer survival: a Swedish population-based study. Lancet Oncol 2007, 8:1001-1006

57. Gudmundsson J, Sulem P, Gudbjartsson DF, Blondal T, Gylfason A, Agnarsson BA, Benediktsdottir KR, Magnusdottir DN, Orlygsdottir G, Jakobsdottir M, Stacey SN, Sigurdsson A, Wahlfors T, Tammela T, Breyer JP, McReynolds KM, Bradley KM, Saez B, Godino J, Navarrete S, Fuertes F, Murillo L, Polo E, Aben KK, van Oort IM, Suarez BK, Helfand BT, Kan D, Zanon C, Frigge ML, et al: Genome-wide association and replication studies identify four variants associated with prostate cancer susceptibility. Nat Genet 2009, 41:1122-1126

doi:10.1186/gm166

Cite this article as: Wiklund F: Prostate cancer genomics: can we distinguish between indolent and fatal disease using genetic markers? Genome

Medicine 2010, 2:45. 